\title{
A retrospective study of ovarian cysts
}

\section{Shivaji Neelgund*, Panchaksharayya Hiremath}

Department of Obstetrics and Gynecology, Sri Venkateshwaraa Medical College Hospital and Research Centre, Ariyur, Pondicherry, India

Received: 18 April 2016

Accepted: 12 May 2016

\section{*Correspondence:}

Dr. Shivaji Neelgund,

E-mail: shivajineelgund5@gmail.com

Copyright: ( ) the author(s), publisher and licensee Medip Academy. This is an open-access article distributed under the terms of the Creative Commons Attribution Non-Commercial License, which permits unrestricted non-commercial use, distribution, and reproduction in any medium, provided the original work is properly cited.

\section{ABSTRACT}

Background: The ovaries are paired sex glands or gonads in female and are concerned with germ cell maturation, storage and its release. The ovaries are also concerned with steroidogenesis. The ovary is covered by a single layer of cuboidal cells known as germinal epithelium. As per the clinical features of the benign ovarian tumors, benign tumors predominantly manifest in late reproductive age.

Methods: This retrospective study is conducted in SVMCH and RC, Ariyur, Pondicherry. During the period of two years (2011-2013).This analysis was done keeping in mind, the objectives to know the histopathology and clinical symptoms of patients who required the surgery for adnexal mass (ovarian mass). We have operated most of the cases, laproscopically; however few patients who had large mass and unfit for laparoscopic surgery underwent conventional laparotomy.

Results: As we analyzed retrospectively these 123 cases, there were 59 (47.96\%) cases of benign cystic ovarian tumors, of which $23(18.69 \%)$ cases were serous cystadenoma which was the commonest of all in this study. This was followed by mucinous cystadenoma 12 (9.75\%).In our study the least common benign tumor was serous fibroadenoma, which was seen in $2(1.62 \%)$. We came across only one (1.23\%) case of malignant ovarian tumor, which was found in a postmenopausal woman.

Conclusions: Unilocular simple ovarian cysts are usually functional ovarian cysts and resolve spontaneously. Therapy by 3 to 6 months of Oral Contraceptives, usually resolves them and this also helps to distinguish between physiological and pathological ovarian cysts

Keywords: Ovarian tumors, Laparoscopy, Functional Cyst, Serous cystadenoma, Ovary, Contraceptive pills

\section{INTRODUCTION}

The ovaries are paired sex glands or gonads in female and are concerned with germ cell maturation, storage and its release. The ovaries are also concerned with steroidogenesis. The ovary is covered by a single layer of cuboidal cells known as germinal epithelium. The substance of the gland consists of outer cortex which shows the structural changes during ovular cycle. The medulla consists of connective tissue, some unstripped muscles, blood vessels and nerves. Medulla also has hilus cells which are homologous to the interstitial cells of the testes.
The non-neoplastic enlargement of the ovary is usually due to accumulation of fluid inside the functional unit of the ovary. The functional cysts of the ovary are related to temporary hormonal disorders. The functional cysts can be distinguished from the neoplastic cysts as they are, usually 6-8 cm, asymptomatic, regress spontaneously, are unilocular, contains clear fluid and lining epithelium is functional epithelium of the unit from which it arises. ${ }^{1}$

As per the clinical features of the benign ovarian tumors, the benign tumors predominantly manifest in late reproductive age. However, dermoid and mucinous cystadenoma are common in reproductive age group. 
There is no correlation with parity and the benign ovarian tumors. Most tumors are asymptomatic; however, some may show lump, heaviness, or dull ache in the abdomen. USG and color Doppler is diagnostic tool which helps in making a diagnosis and also to distinguish the benign from malignant.

The ovarian cysts or the benign ovarian tumors will show some complications like, torsion, intracystic hemorrhage, infection, pseudo mucinous peritonitis or malignancy. Sometimes clinician encounters para ovarian cysts which are purely benign. ${ }^{1}$ These are misdiagnosed as ovarian cysts; however these cysts will remain in the same size after 12 weeks of hormonal (OCP) treatment. Similar behaviour and misinterpretation can occur with hydrosalpinx. The incidence of ovarian tumor amongst gynaecological admission varies from 1-3\%. About $75 \%$ of these are benign in nature.

\section{METHODS}

This retrospective study is conducted in Sri Venkateshwaraa Medical College Hospital and Research Centre, Ariyur, Pondicherry, India during the period of two years (2011-2013). This analysis was done keeping in mind the objectives to know the histopathology and clinical symptoms of patients who required the surgery for adnexal mass (ovarian mass). We have operated most of the case, laproscopically; however few patients who had large mass and unfit for laparoscopic surgery underwent conventional laparotomy. Indication for surgery were large mass $>6 \mathrm{~cm}$, mass with symptoms and solid components, persisting ovarian cyst $<6 \mathrm{~cm}$ even after 3 months of oral contraceptive treatment, acute symptoms suggestive of torsion.

Many of our adnexal masses were diagnosed by chance on ultrasonography which was done for vague symptoms, few patients came with USG report with adnexal mass, which were done outside.

All elective cases were done after routine investigations, anaesthetic check-up and with valid consent after explaining procedure and complications of the surgery (laparoscopy /laparotomy)

CA-125 was not done routinely for all patients except for few patients who were more than 40 years or any high risk for malignancy. The decision for cystectomy or ovariotomy was taken on the operation table. Specimen was retrieved by colpotomy or through the side port of laparoscopy.

All the tissues were sent for histopathology analysis on the day of the surgery. Our patients were discharged 48hrs after laparoscopic surgery and after 7 days after laparotomy. All patients were followed up after 2 week with histopathologic report, retrospectively all the clinical symptoms, and histopathology reports are analysed to know the fact whether really, these patients required the surgery.

\section{RESULTS}

This study was undertaken in Sri Venkateshwaraa Medical College Hospital and Research Centre, Ariyur, Pondicherry, India. This is a tertiary care center, where we attend around 30-40 gynaecology patients per day in the outpatient department. This study was conducted during the period of 2011-2013, during this period we came across 123 cases of ovarian cystic masses. The diagnoses of these cystic masses were based on the symptoms, clinical examination, trans-abdominal or trans-vaginal ultrasonography.

Table 1: Incidence of ovarian cysts and tumors.

\begin{tabular}{|lll|}
\hline $\begin{array}{l}\text { Type of cystic lesion } \\
\text { Serous cystadenoma } \\
\text { carcinoma }\end{array}$ & 1 & 1.23 \\
\hline $\begin{array}{l}\text { Borderline serous } \\
\text { papillary tumor }\end{array}$ & 2 & 1.62 \\
\hline $\begin{array}{l}\text { Borderline mucinous } \\
\text { tumor }\end{array}$ & 2 & 1.62 \\
\hline Serous cystadenoma & 23 & 18.69 \\
\hline $\begin{array}{l}\text { Mucinous } \\
\text { cystadenoma }\end{array}$ & 12 & 9.75 \\
\hline Serous adenofibroma & 2 & 1.62 \\
\hline $\begin{array}{l}\text { Mature Cystic } \\
\text { teratoma }\end{array}$ & 22 & 17.89 \\
\hline Haemorrhagic cyst & 10 & 8.13 \\
\hline Endometriotic cyst & 16 & 13.00 \\
\hline Para ovarian Cyst & 2 & 1.62 \\
\hline Simple follicular cyst & 20 & 16.26 \\
\hline Corpus luteum cyst & 11 & 8.94 \\
\hline Total & 123 & 100 \\
\hline
\end{tabular}

As we analysed retrospectively these 123 cases, there were $59(47.96 \%)$ cases of benign cystic ovarian tumors, of which $23(18.69 \%)$, cases were serous cystadenoma which was the commonest of all in this study. This was followed by mucinous cystadenoma 12 (9.75\%).In our study the least common benign tumor was serous fibroadenoma, which was seen in $2(1.62 \%)$. We came across only one $(1.23 \%)$ case of malignant ovarian tumor, which was found in a postmenopausal woman. Border malignancies were encountered in 4 patients $(3.25 \%)$, of which 2 were border line papillary serous tumor and 2 were of border line mucinous tumor.

In our study there were 31 cases of functional cysts, of which 20 (16.26\%) were Simple follicular cysts and 11 $(8.94 \%)$ corpus luteum cysts. Majority of these cases responded for the three months of cyclical oral contraceptive pills. The patients with no response were subjected for the laparoscopy, which were turned to be cases of either paraovarian or endometriotic cysts. 
Among these tumors 2 cases were para ovarian cysts and $16(13 \%)$ endometriotic cysts (Table 1$)$.

Table 2: Symptomology of cystic ovarian tumors.

\begin{tabular}{|lll|}
\hline Presentation. & No. of cases & $\%$ \\
\hline Abdominal pain & 83 & 67.5 \\
\hline Abdominal mass & 7 & 5.7 \\
\hline Menorrhagia/dysmenorrhoea & 12 & 9.75 \\
\hline Incidental finding & 12 & 9.75 \\
\hline Infertility & 6 & 4.9 \\
\hline Post-menopausal bleeding & 3 & 2.44 \\
\hline
\end{tabular}

Table 3: Correlation between histopathology and USG findings.

\begin{tabular}{|c|c|c|}
\hline Histopathology & No. & USG report \\
\hline Corpus luteal cyst & 11 & $\begin{array}{l}\text { Simple unilocular cyst- } \\
11\end{array}$ \\
\hline Paraovarian cyst & 2 & Simple unilocular cyst- 2 \\
\hline Follicular cyst & 20 & $\begin{array}{l}\text { Anechoic with septa-8 } \\
\text { Simple unilocular cyst- } \\
12\end{array}$ \\
\hline Endometriotic cyst & 16 & $\begin{array}{l}\text { Simple unilocular cyst- } 8 \\
\text { Cyst with internal echos- } \\
6 \\
\text { Anechoic with septa-2 }\end{array}$ \\
\hline $\begin{array}{l}\text { Mature cystic } \\
\text { teratoma }\end{array}$ & 22 & $\begin{array}{l}\text { Cysts with hyperechoic } \\
\text { area/calcification- } 22\end{array}$ \\
\hline Serous cysadenoma & 23 & $\begin{array}{l}\text { Anechoic cysts- } 11 \\
\text { Anechoic cysts with } \\
\text { septa-5 } \\
\text { Anechoic cysts with } \\
\text { echogenic foci-7 }\end{array}$ \\
\hline $\begin{array}{l}\text { Mucinous } \\
\text { cystademona }\end{array}$ & 12 & $\begin{array}{l}\text { Multi septate anechoic } \\
\text { cysts- } 8 \\
\text { Simple anechoic cysts-4 }\end{array}$ \\
\hline $\begin{array}{l}\text { Serous } \\
\text { adenofibroma }\end{array}$ & 2 & Solid tumor-2 \\
\hline Hemorrhagic Cyst & 10 & Anechoic cysts- 10 \\
\hline $\begin{array}{l}\text { Serous } \\
\text { cystadenocarcinoma }\end{array}$ & 1 & $\begin{array}{l}\text { Multi septate anechoic } \\
\text { cysts with solid } \\
\text { components-1 }\end{array}$ \\
\hline $\begin{array}{l}\text { Borderline } \\
\text { mucinous tumor }\end{array}$ & 2 & $\begin{array}{l}\text { Multi septate anechoic } \\
\text { cysts with solid } \\
\text { components- } 2\end{array}$ \\
\hline $\begin{array}{l}\text { Borderline papillary } \\
\text { serous tumor }\end{array}$ & 2 & $\begin{array}{l}\text { Multi septate anechoic } \\
\text { cysts-2 }\end{array}$ \\
\hline
\end{tabular}

Majority of the patients had presented with pain abdomen, which was vague and associated with a feeling of heaviness in the lower abdomen. However, three $(2.43 \%)$ patients had presented with severe pain abdomen and there were signs of acute abdomen. These patients were clinically suspected to have twisted ovarian cysts. A diagnosis was confirmed by Ultra- sonography and Doppler study. In the reproductive age group $12(9.75 \%)$ cases had presented with menorrhagia and dysmenorrhea.
Only five were diagnosed as cystic ovarian lesion by clinical examination. However, all were diagnosed by Ultra-sonography. Only 7 (5.7\%) patients presented with mass per abdomen. Only $3(2.44 \%)$, patients presented as Postmenopausal bleeding, and were diagnosed by ultrasonography as anechoic multiseptate ovarian cyst in 2 cases and one as anechoic multiseptate ovarian cyst with solid components. All were borderline malignant ovarian tumors, which were confirmed postoperatively by the histopathology (Table 2).Twenty (16.26\%) patients were found to have cystic ovarian masses incidentally by Ultrasonography, of which 12 cases were investigated for infertility.

Mature cystic teratoma, which numbered 22 cases (17.89\%), was diagnosed by ultra-sonography as cystic ovarian lesion with hyperechoic areas and calcification. The serous cystadenoma were reported as, anechoic cysts in 11 cases, anechoic cyst with septa in 5 cases and anechoic cyst with echoic foci in 7 cases. Functional ovarian cysts were reported as simple unilocular cysts, and Haemorrhagic cysts as anechoic cysts. Ultrasonography results were fairly correlated with the histopathological diagnosis (Table 3).

Table 4: Age wise distribution of ovarian tumors.

\begin{tabular}{|llllllll|}
\hline Histopathology & \multicolumn{7}{c|}{ Age in years } \\
\hline & $<19$ & $\begin{array}{l}20- \\
29\end{array}$ & $\begin{array}{l}30- \\
39\end{array}$ & $\begin{array}{l}40- \\
50-\end{array}$ & $\begin{array}{l}59 \\
69\end{array}$ & $>70$ \\
\hline $\begin{array}{l}\text { Serous } \\
\text { cystadenoma }\end{array}$ & 1 & 8 & 12 & 1 & 1 & nil & nil \\
\hline $\begin{array}{l}\text { Mucinous } \\
\text { cystadenoma }\end{array}$ & 1 & 5 & 3 & 2 & 1 & nil & nil \\
\hline $\begin{array}{l}\text { Mature cystic } \\
\text { teratoma }\end{array}$ & 2 & 15 & 3 & 1 & nil & 1 & nil \\
\hline $\begin{array}{l}\text { Serous } \\
\text { adenofibroma }\end{array}$ & nil & nil & 2 & nil & nil & nil & nil \\
\hline Follicular cyst & nil & 8 & 10 & 2 & nil & nil & nil \\
\hline $\begin{array}{l}\text { Corpus luteal } \\
\text { cyst }\end{array}$ & nil & 7 & 4 & nil & nil & nil & nil \\
\hline $\begin{array}{l}\text { Para ovarian } \\
\text { cyst }\end{array}$ & nil & 2 & nil & nil & nil & nil & nil \\
\hline $\begin{array}{l}\text { Haemorrhagic } \\
\text { cyst }\end{array}$ & 1 & 6 & 2 & 1 & nil & nil & nil \\
\hline $\begin{array}{l}\text { Endometriotic } \\
\text { cyst }\end{array}$ & 2 & 8 & 5 & 1 & nil & nil & nil \\
\hline $\begin{array}{l}\text { Serous cyst } \\
\text { adenocarcinoma }\end{array}$ & nil & nil & nil & nil & 1 & nil & nil \\
\hline $\begin{array}{l}\text { Borderline } \\
\text { mucinous tumor }\end{array}$ & nil & nil & nil & nil & 1 & 1 & nil \\
\hline $\begin{array}{l}\text { Borderline } \\
\text { papillary serous } \\
\text { tumor }\end{array}$ & nil & nil & nil & nil & 1 & 1 & nil \\
\hline
\end{tabular}

The age of the patients in our study ranged from 16yrs to $70 \mathrm{yrs}$. The maximum number of cystic ovarian tumors occurred in the age group of 20 to 29 (years-59) (47.96\%) and in the age group 30 to 39 (years-41) (33.33\%) cases. The total numbers of cases in the age group 16 to 39 years were $100(81.30 \%)$. The youngest patient was aged 
16 years with mature cystic teratoma and the oldest patient was aged 64 years, with borderline papillary serous tumor. The one who had serous cyst adenocarcinoma was aged 58 years (Table 4).

\section{DISCUSSION}

Cystic ovarian masses are commonly encountered ovarian tumors in women and they present with vague symptoms. Cystic ovarian lesions are either physiological, or pathological. They can occur as functional cysts, benign or malignant tumors. ${ }^{2}$ It is very essential to differentiate as it requires executing a definitive treatment. As the symptoms are being vague in making the definitive diagnosis. It is advised to take the combination of clinical examination, Ultra-sonography and tumor marker CA 125 levels to arrive at proper diagnosis. However, histopathology gives the final diagnosis. ${ }^{3}$

Malignancy is usually less in ovary as the ovary is a partially cystic organ. Ovarian malignancy is rarely seen in the age group of 15-40 years. ${ }^{4}$ The functional, nonneoplastic and benign cystic ovarian lesions are common in the younger age. However, the chance of malignancy increases as the age advances. ${ }^{5}$

Functional ovarian cysts, which are unilocular usually resolve spontaneously. ${ }^{6}$ Oral contraceptives, over a period of 3 to 6 months, also resolves the functional ovarian cysts, this also helps to distinguish a physiological ovarian cyst from a pathological one. ${ }^{7,8} \mathrm{~A}$ simple, unilocular cystic ovarian lesion, can be monitored with serial ultra-sonography and CA 125, for its resolution over a period of time and unnecessary excision avoided. A unilocular echo free ovarian cyst, to be malignant, is less than $1.6 \% .^{9-11}$

This descriptive study was undertaken, to analyse and correlate the histopathological diagnosis with the, clinical presentations, age factors and ultra-sound findings of the 123 cases of cystic ovarian masses, during the study period.

In our study, abdominal pain was the commonest symptom, $83(67.5 \%)$ cases; same incidence was reported by Kayastha. $^{12}$

In this study the incidence of benign cystic ovarian tumors was $59(47.9 \%)$. The benign epithelial was 37 $(62.71 \%)$ cases. The benign germ cell tumor-mature cystic teratoma was $22(37.3 \%)$. In our study benign cystic ovarian tumor was the commonest, the age incidence was 20 to 49 years, and pain abdomen was the commonest symptom. Similar findings were reported by Pilli, Gupta and Kayastha. ${ }^{13,14}$

Among the benign epithelial tumors, serous cystadenoma were $23(38.98 \%)$. mucinous cystadenoma were 12 $(20.34 \%)$ and serous fibroadenoma were 2 (3.39\%).
Bhattachery et al reported benign epithelial tumors $(61.60 \%)$ and mature cystic teratoma $(24.8 \%) .{ }^{15}$ Gupta et al reported the incidence of benign epithelial tumors as $(48.8 \%)$ and mature cystic teratoma as $(23.9 \%)$. Mondal et al reported, serous cystadenoma $(29.9 \%)$ mucinous cystadenoma $(11.1 \%)$ and mature cystic teratoma $(15.9 \%) .{ }^{16}$ In our study also, benign epithelial tumors are more common and there is a preponderance of serous cystadenoma over mucinous cystadenoma. ${ }^{13,14}$ Maliheh et al reported, that the commonest benign ovarian tumor was serous cystadenoma (38\%) followed by mature cysticteratoma $(30 \%)$, mucinous cystadenoma (22\%), Yasmin et al reported serous cystadenoma (24\%) and mature cysticteratoma $(18 \%){ }^{17,18}$

Non-neoplastic cystic ovarian tumors in our study were $59(47.9 \%)$, of which simple follicular cyst were 20 cases and Corpus luteum cysts 11 cases. The endometriotic cysts in our study were $16(13 \%)$. Maliheh reported Functional cysts as $(57.54 \%)$ and endometriotic cysts as $(5.9 \%)$. Cohen et al reported that ovarian endometriosis is common. $^{19}$

Serous cyst adenocarcinoma was the malignant ovarian tumor in our study, one case $(1.23 \%)$. There were 2 $(1.62 \%)$ cases of borderline serous papillary tumor and 2 $(1.62 \%)$ cases of borderline mucinous tumor, in our study, Same findings were reported by Mondal et al and Bhattachery et al that epithelial malignant tumors are the commonest.

Kroon et al reported that ultra-sonography diagnosed Mature Cystic teratoma accurately. ${ }^{20}$ In our study all of 22 cases of mature cystic teratoma were diagnosed by ultrasonography.

\section{CONCLUSION}

Unilocular simple ovarian cysts are usually functional ovarian cysts and resolve spontaneously. Therapy by 3 to 6 months of oral contraceptives, usually resolves them and this also helps to distinguish between physiological and pathological ovarian cysts. Benign ovarian tumors exhibit a wide range of clinical and histopathological patterns. Pain abdomen is the commonest symptom in cystic ovarian tumors. Ultrasonography accurately diagnosis mature cystic teratoma. Epithelial tumors are commonest of the benign ovarian tumors.

Funding: No funding sources

Conflict of interest: None declared

Ethical approval: The study was approved by the Institutional Ethics Committee

\section{REFERENCES}

1. Dutta DC. Benign Ovarian Lesions. In: Hiralal Konar, eds. Text Book of Gynaecology. 7th ed. New Delhi: Jaypee Medical Publishers; 2013:471-79. 
2. Grimes DA, Jones LB, Lopez LM, Schulz KF. Oral Contraceptives for functional ovarian cysts. Cochrane Database Syst Rev. 2014;4:CD006134.

3. Alacazar JI, Merce LT, Laparte C, Jurado M. LopezGarcia G. Anew scoring system to differentiate benign from malignant adenexal masses. Am J Obstet Gynecol. 2003;188:685-92.

4. Cannaistra SA. Cancer of ovary. N Eng J Med. 2004;351:2519-29.

5. Hongqian L, Xiangao W, Dongohao L, Zhihong L, Gang S. Ovarian masses in children and adolescent in China; analysis of 203 cases. J Ovarian Res. 2013:6:47.

6. Modesitt SC. Risk of malignancy in unilocular ovarian cystic tumors less than 10 centimeters in diameter. ObstetGynaecol. 2003;102(3):594-9.

7. Vessey M. Ovarian neoplasms, functional cysts and oral contraceptives. Br Med J. 2009;294:1518-20.

8. Spanso WJ. Preoperative hormonal therapy of cystic adexanal masses Am J ObstetGynecol. 2011;116:551-6.

9. Medeiros LR, Rosa DD, Bozzetti MC, Fachel JM, Furness S, Garry R, et al. Laproscopy versus Laparotomy for benign ovarian tumor. Cochrane Database Syst Rev. 2009;(2):CD004751.

10. Bottomley C. Bourne T. Diagnosis and management of ovarian cyst accidents. Best Pract Res Clin Obstet Gynaecol. 2009;23:711-24.

11. Ekerhovd E, Wienerroith H, Staudach A, Greenberg S. Preoperative assessment of unilocular adnexal cysts by transvaginal ultrasonography; a comparison between ultrasonographic morphology, imaging and histopathologic diagnosis. Am J Obste Gynecol. 2001;188:48-54.

12. Kayastha S. Study of Ovarian Tumors in Nepal Medical College Teaching Hospital Nepal. Medcoll J. 2009; 11:200-2.

13. Pilli GS, Suneeta KP, Dhaded AV, Yenni VV. Ovarian tumors, study of 282 cases. J Indian M Ass. 2002:100:420, 423-4.

14. Gupta N, Bishit D, Agarwal AK, Sharma VK. Retrospective and prospective study of ovarian tumors and tumor like lesions. Indian J Pathol Microbiol. 2007;50:525-7.

15. Bhattacharya MM. A clinicopathological analysis of 270 ovarian tumors. J Post grad Med. 1980;26:103.

16. Mondal SK. Histologic pattern, bilaterality and clinical evaluation of 957 ovarian neoplasms; A 10 year study in a tertiary hospital of eastern India. J Can Res Ther. 2011;7:433-7.

17. Malineh A. Surgical histopathology of benign ovarian cysts. A multicentric study. Iranian Journal of Pathology. 2010;5(3):132-6.

18. Yasmin S. Clinico histopathological Pattern of Ovarian Tumors in Peshawar Region. J Ayub Med Coll Abbottabad. 2008;4:20.

19. Cohen M. Sites of endometriosis. Rev Prat. 1990;40:1091-6.

20. DeKroon CD. Vander Sandy. HavenHouwe. Lingen JC, Jansen FW. Sono graphic assessment of nonmalignant ovarian cysts. Does sonohistology exists? Hum Reprod. 2004;19:2138-43.

Cite this article as: Neelgund S, Hiremath P. A retrospective study of ovarian cysts. Int J Reprod Contracept Obstet Gynecol 2016;5:1969-73. 